\title{
Removal of Hardness of Earth Alkaline Metals from Aqueous Solutions by Ion Exchange Method
}

\author{
Gulten Cetin \\ Chemistry Department, Faculty of Science and Art, Yildiz Technical University, Campus of Davutpasa, Esenler, \\ 34220 Istanbul, Turkey \\ Correspondence should be addressed to Gulten Cetin; gultencetin612@gmail.com
}

Received 28 November 2013; Accepted 31 December 2013; Published 23 February 2014

Academic Editors: N. Egashira, V. A. Lemos, and A. Lewenstam

Copyright (C) 2014 Gulten Cetin. This is an open access article distributed under the Creative Commons Attribution License, which permits unrestricted use, distribution, and reproduction in any medium, provided the original work is properly cited.

\begin{abstract}
An ion exchange process was introduced as an approach for softening of artificial hard water solutions. A strong acid cation exchange resin, Amberlite IR $120\left[\mathrm{Na}^{+}\right]$, was used to reduce the hardness of water with the matrix of styrene-divinylbenzene copolymer having functional group as sulfonate. The ion exchange behavior of the ions of calcium and magnesium in synthetic solutions of hard water was investigated with the variables depending on $\mathrm{pH}$, stirrer speed of the solutions and amount of the resin as a function of contact time between resin phase and hard water solution. The maximum ion exchange capacity was found to be $68 \mathrm{mg} / \mathrm{g}$ for Ca(II) and $12 \mathrm{mg} / \mathrm{g}$ for $\mathrm{Mg}(\mathrm{II})$ at $\mathrm{pH}$ 3.0. The method is a simple and efficient one to remove calcium and magnesium hardness from hard water solutions with the resin having more selectivity for calcium.
\end{abstract}

\section{Introduction}

The existence of the soluble $\mathrm{Ca}(\mathrm{II})$ and $\mathrm{Mg}(\mathrm{II})$ salts has caused unsuitable behavior of hard water solutions for drinking, watering, and the purposes of industrial. The ionic impurities can lead to problems in cooling and heating systems, steam generation, and manufacturing. The high calcium and magnesium concentrations have resulted in clogging of pipelines and heat exchangers through scaling as the form at carbonate, sulfate, or phosphate precipitates. Therefore the necessity of obtaining water having low level of hardness has taken place inside important occupational areas for industries such as leather production [1]. The common methods used for removal of the metals of earth alkaline from aqueous solutions and softening of water can be classified as chemical precipitation, ultrafiltration, reverse osmosis, electrodialysis, adsorption, and ion exchange [2-4]. Water softening using electrochemical techniques has gained attention [5]. The packed bed of polypyrrole/polystyrene sulfonate electrodeposited porous carbon electrode has been used for continuous water softening from flowing artificial hard water solutions [6].

The ion exchange resins have numerous commercial and industrial uses particularly in water purification and removal of metal ions at very low concentrations in chemical process of industries [7]. Some polymeric resins having strongly acid sulfonic or weakly acid carboxylic functionalities are usually used in ion exchange processes [8-11]. A method has been focused on the combination of ultrasound and ion exchange for removal of hardness of calcium and magnesium from water [12]. Some methods have been conducted for removing $\mathrm{Ca}$ (II) and $\mathrm{Mg}$ (II) from water by using chelating resins with high selectivity [13-15]. The exchange of $\mathrm{Ca}(\mathrm{II})$ and $\mathrm{Mg}(\mathrm{II})$ from $\mathrm{LiHCO}_{3}$ solution was studied with Amberlite IRC 747 [16]. Applications of polymeric resins containing iminodiacetate have been investigated from aqueous solutions for recovery of $\mathrm{Ca}(\mathrm{II})$ and $\mathrm{Mg}(\mathrm{II})$ [17-23]. Amberlite IRC 748 as $\mathrm{K}^{+}$form was used from potassium chromate solution for removal of $\mathrm{Ca}$ (II) and $\mathrm{Mg}$ (II) [24]. A study was performed on softening of waste geothermal water using ion exchange resins [25].

There are some studies by ion exchange technology using the resin of Amberlite IR 120. Some of them for $\mathrm{Ca}(\mathrm{II})$ removal [26] and magnesium adsorption [27] have been investigated by using empirical kinetic models.

In the present work the main objective of the study is to remove the magnesium and calcium hardness from synthetic solutions of hard water. The selective adsorption equilibrium 


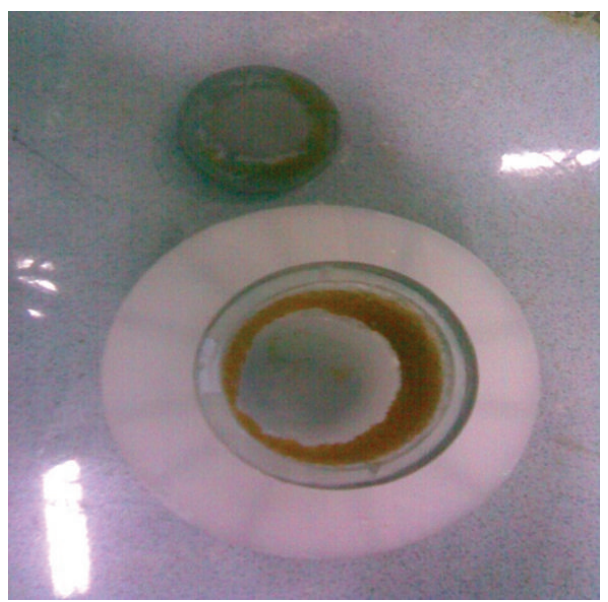

(a)

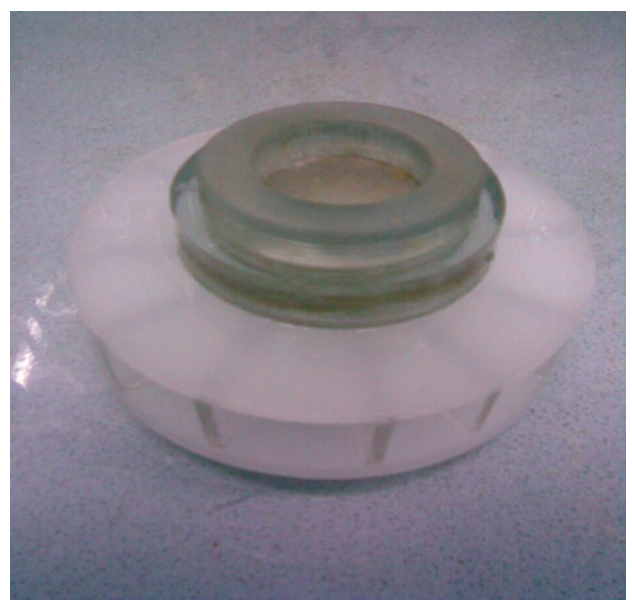

(b)

FIGURE 1: The basket of the resin.

for earth alkaline metals was investigated under different conditions such as $\mathrm{pH}$, stirring speed of the solutions, and amount of the resin as a function of contact time between the phase of resin and synthetic hard water solutions. The examined method was applied for removal of calcium and magnesium hardness of tap water obtained from research laboratory of YILDIZ Technical University, Faculty of Science and Art, Analytical Chemistry Department, Esenler, Istanbul, Turkey.

\section{Experimental}

2.1. Materials. The inorganic chemicals including $\mathrm{CaCI}_{2}$ $2 \mathrm{H}_{2} \mathrm{O}, \mathrm{MgCI}_{2} 6 \mathrm{H}_{2} \mathrm{O}, \mathrm{HCI}$, and $\mathrm{NaOH}$ were obtained from Merck (Darmstadt, Germany) in analytical grade. All solutions were prepared using bidistilled water.

2.2. Ion Exchange Resin. The resin of Amberlite IR $120\left[\mathrm{Na}^{+}\right]$ [28] was used as a strongly acid cation exchanger having copolymer of styrene and divinylbenzene with functional groups of $\mathrm{SO}_{3}{ }^{-} \mathrm{Na}^{+}$in the physical form gel type. The properties and suggested operating conditions of the resin have been shown in Tables $1(\mathrm{a})$ and $1(\mathrm{~b})$.

The resin was washed three times with the solutions of, respectively, $1.0 \mathrm{~mol} / \mathrm{L} \mathrm{HCI}$ and $1.0 \mathrm{~mol} / \mathrm{L} \mathrm{NaOH}$ before its use to remove or reduce possible organic and inorganic impurities. It was then washed with bidistilled water and converted to $\mathrm{H}^{+}$form from $\mathrm{Na}^{+}$by flushing in fixed bed with $1.0 \mathrm{~mol} / \mathrm{L}$ $\mathrm{HCI}$. The resin in $\mathrm{H}^{+}$form was finally washed with water and used throughout the experiments.

2.3. Preparing of the Solutions of Synthetic Hard Water. The synthetic solutions of hard water have been prepared as stock solution in the volume of $5.0 \mathrm{~L}$. The volume of $950 \mathrm{~mL}$ of the stock solution was taken to the batch reactor and after the $\mathrm{pH}$ of the solution was adjusted to desired value the solution was transferred to the flask in the volume of $1.0 \mathrm{~L}$ by diluting to the volume and it was used as synthetic solution of hard water. The hardness of calcium and magnesium of the solutions with
TABLE 1: Manufacturer data of the resin [28].

(a) The properties of the resin, Amberlite IR $120\left[\mathrm{Na}^{+}\right]$

\begin{tabular}{ll}
\hline Physical form & Amber spherical beads \\
Matrix & Styrene-divinylbenzene copolymer \\
Functional group & Sulfonate \\
Ionic form as shipped & $\mathrm{Na}^{+}$ \\
Total exchange capacity & $>2.00 \mathrm{eq} / \mathrm{L}\left(\mathrm{Na}^{+}\right.$form $)$ \\
Moisture holding capacity & 45 to $50 \%\left(\mathrm{Na}^{+}\right.$form $)$ \\
Shipping weight & $840 \mathrm{~g} / \mathrm{L}$ \\
Uniformity coefficient & $<1.9$ \\
Harmonic mean size & 0.600 to $0.800 \mathrm{~mm}$ \\
$<0.300$ mm & $2 \% \max$ \\
Maximum reversible swelling Na & $\rightarrow \mathrm{H}^{+}<11 \%$ \\
\hline
\end{tabular}

(b) Suggested operating conditions of the resin

\begin{tabular}{lccc}
\hline Maximum operating temperature & $135^{\circ} \mathrm{C}$ \\
Minimum bed depth & \multicolumn{3}{c}{$700 \mathrm{~mm}$} \\
Service flow rate & $\mathrm{HCI}$ & $\mathrm{H}_{2} \mathrm{SO}_{4}$ & $\mathrm{NaCI}$ \\
Regenerant & 50 to 150 & 60 to 240 & 80 to 250 \\
Level (g/L) & 5 to 8 & 0.7 to 6 & 10 \\
Concentration (\%) & \multicolumn{3}{c}{30 minutes } \\
Minimum contact time & $2 \mathrm{BV}$ at regeneration flow rate \\
Slow rinse & 2 to $4 \mathrm{BV}$ at service flow rate \\
Fast rinse &
\end{tabular}

state of initial and equilibrium is shown as degree of French hardness (FH) in Tables 4, 5, and 6 and in Figure 1.

2.4. Preparing of the Solutions for Analysis. The volume of $0.5 \mathrm{~mL}$ of the solution of synthetic hard water was taken to the flask in the volume of $100 \mathrm{~mL}$ and diluted to the volume by distilled water.

2.5. Procedure. The batch experiments were carried out to determine the efficiency of removal of calcium and 
TABLE 2: Instrumental parameters for determination of calcium and magnesium [29].

\begin{tabular}{lcc}
\hline Instrumental parameters & Calcium & Magnesium \\
\hline Wave length $(\mathrm{nm})$ & 442,67 & 442,67 \\
Slit width $(\mathrm{nm})$ & 2,7 & 2,7 \\
Fuel & Acetylene/air & Acetylene/air \\
Lamp current $(\mathrm{mA})$ & 20 & 20 \\
Optimum working range & $(0.5-2.5) \mathrm{mg} / \mathrm{L}$ & $(0.2-1.0) \mathrm{mg} / \mathrm{L}$ \\
\hline
\end{tabular}

magnesium hardness from synthetic solution of hard water. The sample of $5.0 \mathrm{~g}$ of the resin in hydrogen form was put into basket of the resin. The basket of the resin was inserted to the mechanical stirrer with the model of Heildolph RZR 2021. The mechanical stirrer was placed into the vessel of reaction containing synthetic solution of hard water in the volume of 1.0 L. The basket stirrer was moved in the solution for one hour while the stirrer works at constant speed. The apparatus of the resin basket has been shown in Figure 1.

This procedure was applied by using synthetic solutions of hard water having comparable amount of calcium and magnesium hardness. The samples of $500 \mu \mathrm{L}$ were taken from solution to measure concentration of the calcium and magnesium for each $10 \mathrm{~min}, 20 \mathrm{~min}, 30 \mathrm{~min}, 40 \mathrm{~min}, 50 \mathrm{~min}$, and $60 \mathrm{~min}$. The samples were diluted to $100 \mathrm{~mL}$ and acidified with solution of nitric acid. The concentrations of calcium and magnesium were determined by an atomic absorption spectrophotometer with a model of Perkin Elymer and airacetylene flame. The balance of the model of Sartorius A 200 $S$ was used for the all weights. Table 2 shows the instrumental parameters for determination of calcium and magnesium by atomic absorption spectrophotometry.

\section{Results and Discussion}

3.1. Method for Removal of Calcium(II) and Magnesium(II) Hardness. The ion exchange process was developed to remove calcium and magnesium hardness from synthetic hard water solutions by using the resin of Amberlite IR 120 in $\mathrm{H}^{+}$form.

The following reactions show that the resin matrix has been converted to the $\mathrm{H}^{+}$form from $\mathrm{Na}^{+}$and the exchange reaction of calcium and magnesium has been summarized:

$$
\begin{aligned}
& \overline{\mathrm{R}-\mathrm{SO}_{3}{ }^{-} \mathrm{Na}^{+}}+\mathrm{HCI} \longrightarrow \overline{\mathrm{R}-\mathrm{SO}_{3}{ }^{-} \mathrm{H}^{+}}+\mathrm{Na}^{+}+\mathrm{CI}^{-} \\
& 2 \overline{\mathrm{R}-\left(\mathrm{SO}_{3}{ }^{-} \mathrm{H}^{+}\right)_{2}}+\mathrm{Ca}^{2+}+\mathrm{Mg}^{2+} \\
& \longrightarrow \overline{\mathrm{R}-\left(\mathrm{SO}_{3}{ }^{-}\right)_{2} \mathrm{Ca}^{2+}}+\overline{\mathrm{R}-\left(\mathrm{SO}_{3}{ }^{-}\right)_{2} \mathrm{Mg}^{2+}}+4 \mathrm{H}^{+}
\end{aligned}
$$

The resin's behavior is different for sorption of calcium and magnesium ions in solution and it is more selective for calcium than magnesium and exchange capacity is more high for calcium. Figures 2 and 3 show this phenomena.

The method of atomic absorption spectrophotometric was used for determination of initial and equilibrium concentrations of ions of calcium and magnesium in solution of hard water by using the equations of calibration curve as it is shown in Table 3.

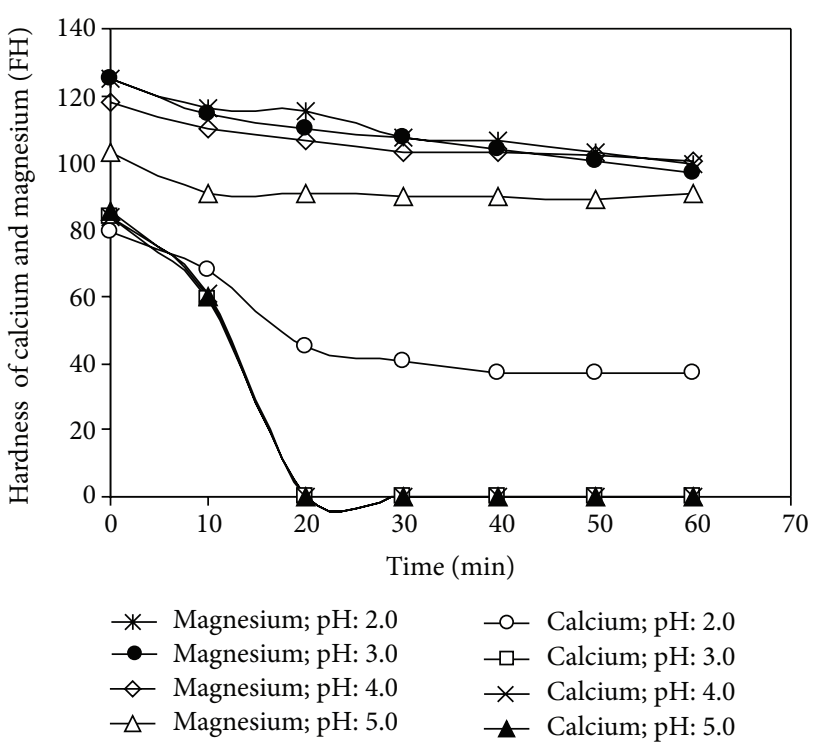

FIGURE 2: The exchange of hardness of calcium and magnesium as a function of initial $\mathrm{pH}$ of the solution (the amount of resin: $5.0 \mathrm{~g}$; the stirring speed of the solution: $115 \mathrm{rpm}$ ).

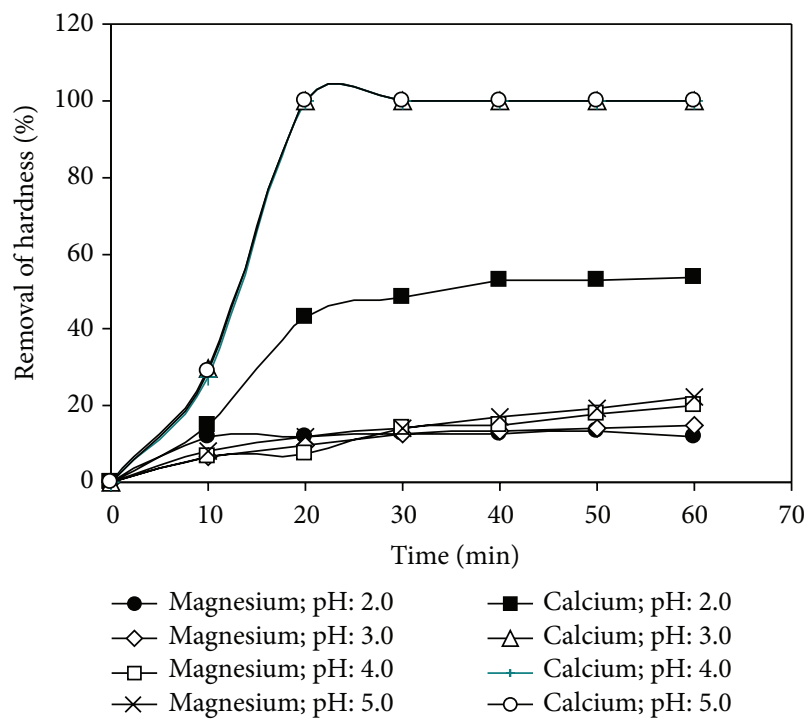

FIGURE 3: The removal of the hardness of calcium and magnesium as a function of initial $\mathrm{pH}$ of the solution (the amount of resin: $5.0 \mathrm{~g}$; the stirring speed of the solution: $115 \mathrm{rpm}$ ).

TABLE 3: The characteristics of the calibration curves.

\begin{tabular}{lcc}
\hline $\begin{array}{l}\text { Earth alkaline } \\
\text { metal }\end{array}$ & $\begin{array}{c}\text { Equation of } \\
\text { calibration curve }\end{array}$ & $\begin{array}{c}\text { Coefficient of } \\
\text { regression }\left(R^{2}\right)\end{array}$ \\
\hline Calcium & $A=0.0328 C-0.0018$ & 0.9994 \\
Magnesium & $A=0.3895 C+0.0145$ & 0.9985 \\
\hline
\end{tabular}

The sorption process of the resin for calcium and magnesium was investigated under experimental conditions such as contact time between resin and aqueous solution, $\mathrm{pH}$, stirring speed of the solution of hard water, and amount of the resin. 
TABLE 4: Experimental conditions depend on effect of $\mathrm{pH}$ for removal of hardness of calcium and magnesium.

\begin{tabular}{|c|c|c|c|c|c|c|}
\hline $\mathrm{pH}$ & $\begin{array}{c}\text { Stirring } \\
\text { speed } \\
(\mathrm{rpm})\end{array}$ & $\begin{array}{c}\text { Resin } \\
\text { dosage } \\
(\mathrm{g})\end{array}$ & $\begin{array}{l}\text { Initial hardness of } \\
\text { calcium }(\mathrm{FH})\end{array}$ & $\begin{array}{l}\text { Hardness of calcium in } \\
\text { equilibrium }(\mathrm{FH})\end{array}$ & $\begin{array}{l}\text { Initial hardness of } \\
\text { magnesium }(\mathrm{FH})\end{array}$ & $\begin{array}{l}\text { Hardness of magnesium in } \\
\text { equilibrium }(\mathrm{FH})\end{array}$ \\
\hline 2 & 115 & 5 & 79.12 & $\begin{array}{c}36.7 \\
(60 \mathrm{~min})\end{array}$ & 124.89 & $\begin{array}{c}99.83 \\
(60 \mathrm{~min})\end{array}$ \\
\hline 3 & 115 & 5 & 83.75 & $\begin{array}{c}0.00 \\
(60 \mathrm{~min})\end{array}$ & 124.89 & $\begin{array}{c}96.80 \\
(60 \mathrm{~min})\end{array}$ \\
\hline 4 & 115 & 5 & 83.75 & $\begin{array}{c}0.00 \\
(60 \mathrm{~min})\end{array}$ & 118.28 & $\begin{array}{c}100.77 \\
(60 \mathrm{~min})\end{array}$ \\
\hline 5 & 115 & 5 & 85.25 & $\begin{array}{c}0.00 \\
(60 \mathrm{~min})\end{array}$ & 102.90 & $\begin{array}{c}90.50 \\
(60 \mathrm{~min})\end{array}$ \\
\hline
\end{tabular}

TABle 5: ((a), (b), and (c)) The exchange of $\mathrm{pH}$ of the solution in equilibrium depends on contact time with the resin according to experimental conditions.

(a)

\begin{tabular}{llllllll}
\hline $\begin{array}{l}\text { Contact time with the resin } \\
\text { (min) }\end{array}$ & 0 & 10 & 20 & 30 & 40 & 50 & 60 \\
pH \\
$\begin{array}{l}\text { (resin dosage: } 5.0 \mathrm{~g}) \\
\text { (stirring speed: } 115 \mathrm{rpm})\end{array}$ \\
pH \\
$\begin{array}{l}\text { (resin dosage: } 5.0 \mathrm{~g}) \\
\text { (stirring speed: } 115 \mathrm{rpm})\end{array}$ \\
$\begin{array}{l}\text { pH } \\
\text { (resin dosage: } 5.0 \mathrm{~g})\end{array}$
\end{tabular}

(b)

\begin{tabular}{lccccccc}
\hline $\begin{array}{l}\text { Contact time with the resin } \\
(\mathrm{min})\end{array}$ & 0 & 10 & 20 & 30 & 40 & 50 & 60 \\
$\mathrm{pH}$ \\
$\begin{array}{l}\text { (resin dosage: } 5.0 \mathrm{~g}) \\
\text { (stirring speed: } 78 \mathrm{rpm})\end{array}$ & 3.00 & 2.84 & 2.25 & 2.23 & 2.22 & 2.21 & 2.21 \\
pH \\
$\begin{array}{l}\text { (resin dosage: } 5.0 \mathrm{~g}) \\
\text { (stirring speed: } 148 \mathrm{rpm})\end{array}$
\end{tabular}

(c)

\begin{tabular}{lccccccc}
\hline $\begin{array}{l}\text { Contact time with the resin } \\
\text { (min) }\end{array}$ & 0 & 10 & 20 & 30 & 40 & 50 & 60 \\
pH \\
$\begin{array}{l}\text { (resin dosage: } 7.5 \mathrm{~g}) \\
\text { (stirring speed: } 115 \mathrm{rpm})\end{array}$ & 3.03 & 2.05 & 2.04 & 2.03 & 2.02 & 2.02 & 2.01 \\
pH \\
$\begin{array}{l}\text { (resin dosage: } 10.0 \mathrm{~g}) \\
\text { (stirring speed: } 115 \mathrm{rpm})\end{array}$ & 3.02 & 2.00 & 1.95 & 1.93 & 1.92 & 1.91 & 1.91 \\
\hline
\end{tabular}

3.2. Effect of Contact Time between Resin and Synthetic Solution of Hard Water on Removal of Hardness of Calcium and Magnesium. The contact time is an important factor in the process of removal of calcium and magnesium from solution of synthetic hard water. The batch experiments were carried out at different contact times as $0,10,20,30,40,50$, and $60 \mathrm{~min}$ with $5.0 \mathrm{~g}$ of the resin and stirring rate of the solution as $115 \mathrm{rpm}$ in the $\mathrm{pH}$ range between 2.0 and 5.0. The equilibrium was established for $60 \mathrm{~min}$.

The uptake of $\mathrm{Ca}(\mathrm{II})$ and $\mathrm{Mg}$ (II) ions and removal of hardness of calcium and magnesium increase rapidly during, respectively, $20 \mathrm{~min}$ and $10 \mathrm{~min}$ at first then the removal of magnesium hardness increases slowly until the equilibrium state was reached as the active sites on the sorbent were filled by ions of calcium. The obtained results has shown that the equilibrium is reached after 20 min under experimental conditions as mentioned. Figure 2 shows the exchange of hardness of magnesium and calcium from synthetic solutions of hard water with the $\mathrm{pH}$ range between 2 and 5 .

3.3. Effect of pH on Removal of Hardness of Calcium and Magnesium. The $\mathrm{pH}$ of the solution of hard water has significant effect on affinity of the resin for calcium and magnesium ions. The sorption of ions of $\mathrm{Ca}(\mathrm{II})$ and $\mathrm{Mg}$ (II) and removal of hardness of calcium and magnesium from solution of hard water were studied with the resin of Amberlite IR $120\left[\mathrm{H}^{+}\right]$ at initial $\mathrm{pH}$ range between 2.0 and 5.0. The initial $\mathrm{pH}$ of the solution of hard water was controlled with $\mathrm{pH}$ meter by adding solutions of hydrochloric acid and sodium hydroxide. In the experiment the temperature, stirring speed, and maximum contact time were kept constant at $298 \mathrm{~K}, 115 \mathrm{rpm}$, and $60 \mathrm{~min}$. Figure 3 shows that the removal amount of hardness of calcium and magnesium from synthetic solutions of hard water depends on contact time with the resin phase in the $\mathrm{pH}$ range of 2.0 and 5.0.

While the amount of removal of calcium hardness has remarkably increased from $40 \%$ to $100 \%$, the amount of removal of magnesium hardness is more restrictive up to about $12 \%$ for equilibrium of $20 \mathrm{~min}$ at higher $\mathrm{pH}$ than 2.0 . The maximum uptake capacity for calcium and magnesium has been determined, respectively, as $68 \mathrm{mg} / \mathrm{g}$ (pH: 3.0) and $12 \mathrm{mg} / \mathrm{g}$ ( $\mathrm{pH}: 3.0$ ). This result has shown that the resin has higher capacity of uptake and selectivity for adsorption of calcium than magnesium. Therefore there is a consideration that the adsorption of calcium ions with anionic functional groups on the surface of the resin has a priority to compare 
TABle 6: Experimental conditions depend on effect of stirring speed for removal of hardness of calcium and magnesium.

\begin{tabular}{|c|c|c|c|c|c|c|}
\hline $\mathrm{pH}$ & $\begin{array}{c}\text { Stirring } \\
\text { speed } \\
(\mathrm{rpm})\end{array}$ & $\begin{array}{c}\text { Resin } \\
\text { dosage } \\
(\mathrm{g})\end{array}$ & $\begin{array}{l}\text { Initial hardness of } \\
\text { calcium }(\mathrm{FH})\end{array}$ & $\begin{array}{l}\text { Hardness of calcium in } \\
\text { equilibrium }(\mathrm{FH})\end{array}$ & $\begin{array}{l}\text { Initial hardness of } \\
\text { magnesium }(\mathrm{FH})\end{array}$ & $\begin{array}{c}\text { Hardness of magnesium in } \\
\text { equilibrium }(\mathrm{FH})\end{array}$ \\
\hline 3 & 78 & 5 & 92.50 & $\begin{array}{c}59.56 \\
(60 \mathrm{~min})\end{array}$ & 134.35 & $\begin{array}{c}108.35 \\
(60 \mathrm{~min})\end{array}$ \\
\hline 3 & 115 & 5 & 83.75 & $\begin{array}{c}0.00 \\
(60 \mathrm{~min})\end{array}$ & 124.89 & $\begin{array}{c}96.80 \\
(60 \mathrm{~min})\end{array}$ \\
\hline 3 & 148 & 5 & 80.05 & $\begin{array}{c}0.00 \\
(60 \mathrm{~min})\end{array}$ & 124.25 & $\begin{array}{c}95.00 \\
(60 \mathrm{~min})\end{array}$ \\
\hline
\end{tabular}

TABLE 7: Experimental conditions depend on effect of amount of the resin for removal of hardness of calcium and magnesium.

\begin{tabular}{|c|c|c|c|c|c|c|}
\hline $\mathrm{pH}$ & $\begin{array}{c}\text { Stirring } \\
\text { speed } \\
(\mathrm{rpm})\end{array}$ & $\begin{array}{c}\text { Resin } \\
\text { dosage } \\
(\mathrm{g})\end{array}$ & $\begin{array}{l}\text { Initial hardness of } \\
\text { calcium }(\mathrm{FH})\end{array}$ & $\begin{array}{l}\text { Hardness of calcium in } \\
\text { equilibrium }(\mathrm{FH})\end{array}$ & $\begin{array}{l}\text { Initial hardness of } \\
\text { magnesium }(\mathrm{FH})\end{array}$ & $\begin{array}{l}\text { Hardness of magnesium in } \\
\text { equilibrium }(\mathrm{FH})\end{array}$ \\
\hline 3 & 115 & 5.0 & 83.75 & $\begin{array}{c}0.00 \\
(60 \mathrm{~min})\end{array}$ & 124.89 & $\begin{array}{c}96.80 \\
(60 \mathrm{~min})\end{array}$ \\
\hline 3 & 115 & 7.5 & 97.90 & $\begin{array}{c}0.00 \\
(60 \mathrm{~min})\end{array}$ & 122.50 & $\begin{array}{c}82.25 \\
(60 \mathrm{~min})\end{array}$ \\
\hline 3 & 115 & 10 & 93.40 & $\begin{array}{c}0.00 \\
(60 \mathrm{~min})\end{array}$ & 119.65 & $\begin{array}{c}33.60 \\
(60 \mathrm{~min})\end{array}$ \\
\hline
\end{tabular}

with magnesium and the sorption of magnesium has a disadvantage with less number of binding sites. Tables 4 and 5(a)5(c) show, respectively, experimental conditions concerned with effect of $\mathrm{pH}$ for removing of hardness of calcium and magnesium from synthetic solutions of hard waters and $\mathrm{pH}$ values of solution in equilibrium depending on initial $\mathrm{pH}$ of the solution and contact time with the resin phase according to experimental conditions.

3.4. Effect of Stirring Speed on Removal of Hardness of Calcium and Magnesium. The effect of stirring speed of the synthetic solution of hard water on removal of hardness of calcium and magnesium was examined with agitation speed between 78 and $148 \mathrm{rpm}$ at $\mathrm{pH}$ of the solution of 3.0 with the resin amount of $5.0 \mathrm{~g}$. The results show that while stirring speed of the solution increases the hardness of calcium and magnesium has reduced and as seen in Figure 4 the removal amount of hardness of calcium and magnesium has risen. The results indicate that the agitation speed of the solution of hard water has an impact on adsorption of calcium and magnesium and removal of hardness degrees.

Table 6 shows experimental conditions concerned with effect of stirring speed for removing of hardness of calcium and magnesium from synthetic solutions of hard waters.

3.5. Effect of Amount of the Resin on Removal of Hardness of Calcium and Magnesium. The removal amount of hardness of calcium and magnesium (Figure 5) from synthetic solutions of hard water was examined in relation to the amount of the resin between 5 and $10 \mathrm{~g}$ under experimental conditions such that $\mathrm{pH}$ of the solution is 3.0 and the stirrer speed of the solution is $115 \mathrm{rpm}$.

According to the results obtained, the removal efficiency of calcium and magnesium hardness increases with rising

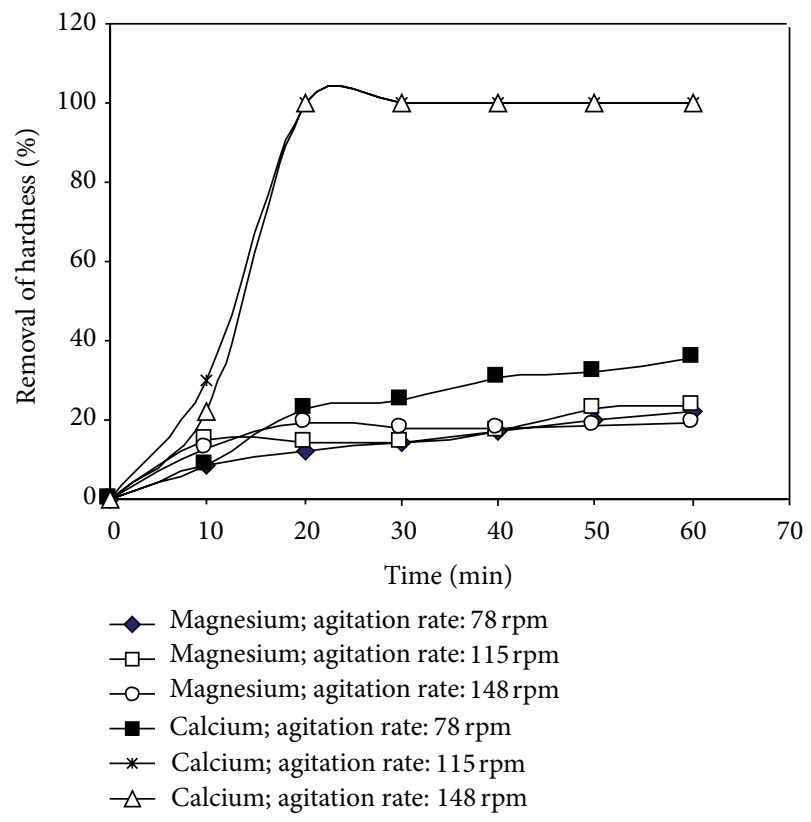

FIGURE 4: The removal of the hardness of calcium and magnesium as a function of agitation speed of the solution (the amount of resin: $5.0 \mathrm{~g}$; the initial $\mathrm{pH}$ of the solution: 3.0 ).

amount of the resin. The amount of the resin provides a great of ion exchange sites to replace of earth alkaline metals for a fixed initial concentration of calcium and magnesium in the solution of hard water. The amount of the resin is an important parameter to obtain the quantitative uptake of calcium and magnesium ions. Table 7 shows experimental conditions concerned with effect of resine dosage for removing hardness of calcium and magnesium from synthetic solution of hard waters. 


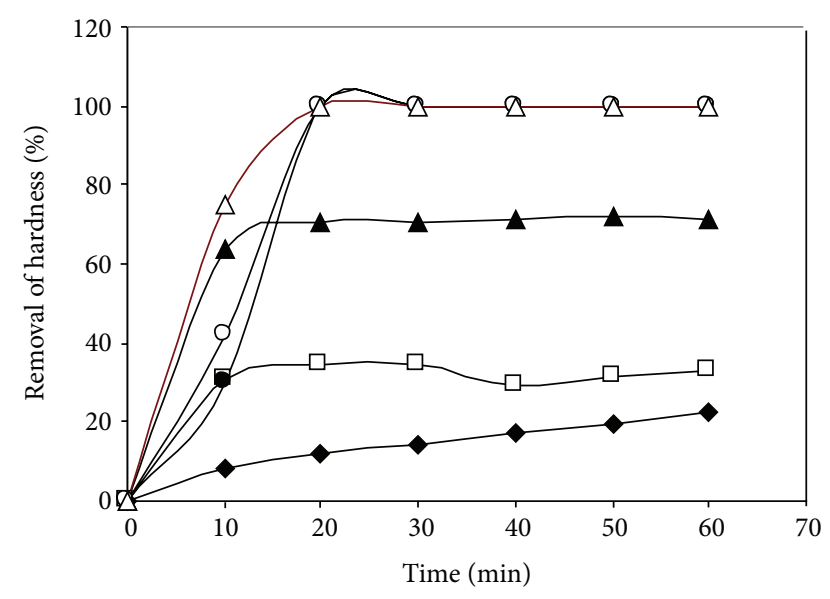

$$
\begin{aligned}
& \multimap \text { Magnesium; resin dosage: } 5.0 \mathrm{~g} \\
& \square-\text { Magnesium; resin dosage: } 7.5 \mathrm{~g} \\
& \neg \text { Magnesium; resin dosage: } 10.0 \mathrm{~g} \\
& \rightarrow \text { Calcium; resin dosage: } 5.0 \mathrm{~g} \\
& \multimap-\text { Calcium; resin dosage: } 7.5 \mathrm{~g} \\
& \triangle \text { Calcium; resin dosage: } 10.0 \mathrm{~g}
\end{aligned}
$$

Figure 5: The removal of the hardness of calcium and magnesium as a function of amount of the resin (the initial $\mathrm{pH}$ of the solution: 3.0; the stirring speed of the solution: $115 \mathrm{rpm}$ ).

\section{Conclusion}

Ion exchange technique has proved to be advantageous over other technologies. Amberlite IR 120, a strong acid cation exchange resin in sodium form, is a low cost ion exchange resin and the experiments have shown that the resin is effective for removal of hardnesses of calcium in the presence of magnesium and softening of waters.

In this study the effects of $\mathrm{pH}$ and stirring speed of the solution and dosage of the resin were searched to remove of hardness level of calcium and magnesium as a function of contact time between the resin and solution of hard water. The optimum operation conditions were determined as: $\mathrm{pH}$ of the solution is 3.0, agitation speed of the solution is $115 \mathrm{rpm}$, amount of the resin is $10 \mathrm{~g}$, and ratio of resin/solution is $1 \mathrm{~g} / 100 \mathrm{~mL}$. The maximum removal efficiency was achieved for calcium and magnesium, respectively, as $100 \%$ and $70 \%$ with contact time of $20 \mathrm{~min}$. The results have shown that the ion exchange rate and capacity of the resin are higher for calcium than magnesium as a competition of sorption of calcium and magnesium and hydrogen ions has occured for resin sites and exchange of calcium has formed in preference to ions of magnesium and hydrogen. The difference of selectivity of the resin for sorption of calcium and magnesium ions has great effect on removal of hardness of calcium with the $\mathrm{pH}$ range higher than 2.0 .

This study has been introduced as a method for removal of calcium from aqueous solutions in the presence of magnesium and $\mathrm{pH}$ range between 2.0 and 5.0. The feasible results have been reached for removal of hardness of calcium and magnesium of tap water obtained from Research Laboratory of YILDIZ Technical University, Analytical Chemistry Department, Istanbul, Turkey. The resin of Amberlite
IR $120\left[\mathrm{Na}^{+}\right]$can be used for treatment applications including softening.

\section{Conflict of Interests}

The author declares that there is no conflict of interests regarding the publication of this paper.

\section{References}

[1] A. F. Viero, A. C. R. Mazzarollo, K. Wada, and I. C. Tessaro, "Removal of hardness and COD from retanning treated effluent by membrane process," Desalination, vol. 149, no. 1-3, pp. 145149, 2002.

[2] Z. C. Lei, K. Qian, and L. H. Liu, Principles and Applications of Industrial Water Treatment, Chemical Industry Press, Beijing, China, 2003.

[3] P. N. Cheremisinoff, Handbook of Water and Wastewater Treatment Technologies, Butterworth-Heinemann, New York, NY, USA, 2001.

[4] S. Rengaraj, J.-W. Yeon, Y. Kim, Y. Jung, Y.-K. Ha, and W.-H. Kim, "Adsorption characteristics of $\mathrm{Cu}(\mathrm{II})$ onto ion exchange resins $252 \mathrm{H}$ and $1500 \mathrm{H}$ : Kinetics, isotherms and error analysis," Journal of Hazardous Materials, vol. 143, no. 1-2, pp. 469-477, 2007.

[5] C. Gabrielli, G. Maurin, H. Francy-Chausson, P. Thery, T. T. M. Tran, and M. Tlili, "Electrochemical water softening: principle and application," Desalination, vol. 201, no. 1-3, pp. 150-163, 2006.

[6] M. M. Saleh, "Water softening using packed bed of polypyrrole from flowing solutions," Desalination, vol. 235, no. 1-3, pp. 319329, 2009.

[7] E. Pehlivan and T. Altun, "The study of various parameters affecting the ion exchange of $\mathrm{Cu}^{2+}, \mathrm{Zn}^{2+}, \mathrm{Ni}^{2+}, \mathrm{Cd}^{2+}$, and $\mathrm{Pb}^{2+}$ from aqueous solution on Dowex $50 \mathrm{~W}$ synthetic resin," Journal of Hazardous Materials, vol. 134, no. 1-3, pp. 149-156, 2006.

[8] E. Maliou, M. Malamis, and P. O. Sakellarides, "Lead and cadmium removal by ion exchange," Water Science and Technology, vol. 25, no. 1, pp. 133-138, 1992.

[9] S. Ahmed, S. Chughtai, and M. A. Keane, "The removal of cadmium and lead from aqueous solution by ion exchange with Na-Y zeolite," Separation and Purification Technology, vol. 13, no. 1, pp. 57-64, 1998.

[10] J. P. Chen and L. Wang, "Characterization of a Ca-alginate based ion-exchange resin and its applications in lead, copper, and zinc removal," Separation Science and Technology, vol. 36, no. 16, pp. 3617-3637, 2001.

[11] P. Outola, H. Leinonen, M. Ridell, and J. Lehto, "Acid/base and metal uptake properties of chelating and weak base resins," Solvent Extraction and Ion Exchange, vol. 19, no. 4, pp. 743-756, 2001.

[12] M. H. Entezari and M. Tahmasbi, "Water softening by combination of ultrasound and ion exchange," Ultrasonics Sonochemistry, vol. 16, no. 3, pp. 356-360, 2009.

[13] K. L. Reece and R. L. Moss, "Removal of contaminating calcium from buffer solutions used in calcium binding assays," Analytical Biochemistry, vol. 365, no. 2, pp. 274-276, 2007.

[14] D. K. Huggins, P. B. Queneau, R. C. Ziegler, and H. H. K. Nauta, "Ion exchange purification of ammonium molybdate solutions," Hydrometallurgy, vol. 6, no. 1-2, pp. 63-73, 1980. 
[15] K. Vaaramaa and J. Lehto, "Removal of metals and anions from drinking water by ion exchange," Desalination, vol. 155, no. 2 , pp. 157-170, 2003.

[16] W.-T. Yi, C.-Y. Yan, and P.-H. Ma, "Removal of calcium and magnesium from $\mathrm{LiHCO}_{3}$ solutions for preparation of highpurity $\mathrm{Li}_{2} \mathrm{CO}_{3}$ by ion-exchange resin," Desalination, vol. 249, no. 2, pp. 729-735, 2009.

[17] Y. Ding and Z. Ji, Production and Application of Chromate Compounds, Chemical Industry Press, Beijing, China, 2003.

[18] S. J. Manio, "Method for Reducing Metal Ion Concentration in Brine Solution," US Patent 6,103,092, 2000.

[19] P. Woodberry, G. Stevens, I. Snape, and S. Stark, "Removal of metal contaminants from saline waters at low temperature by an iminodiacetic acid ion-exchange resin, Thala Valley Tip, Casey Station, Antarctica," Solvent Extraction and Ion Exchange, vol. 23, no. 2, pp. 289-306, 2005.

[20] A. Agrawal and K. K. Sahu, "Influence of temperature on the exchange of alkaline earth and transition metals on iminodiacetate resin," Solvent Extraction and Ion Exchange, vol. 23, no. 2, pp. 265-287, 2005.

[21] A. Agrawal, K. K. Sahu, and J. P. Rawat, "Kinetic studies on the exchange of bivalent metal ions on amberlite IRC-718-an iminodiacetate resin," Solvent Extraction and Ion Exchange, vol. 21, no. 5, pp. 763-782, 2003.

[22] A. Agrawal and K. K. Sahu, "Separation and recovery of lead from a mixture of some heavy metals using Amberlite IRC 718 chelating resin," Journal of Hazardous Materials, vol. 133, no. 1-3, pp. 299-303, 2006.

[23] M. Laikhtman, J. Riviello, and J. S. Rohrer, "Determination of magnesium and calcium in $30 \%$ sodium chloride by ion chromatography with on-line matrix elimination," Journal of Chromatography A, vol. 816, no. 2, pp. 282-285, 1998.

[24] Z. Yu, T. Qi, J. Qu, L. Wang, and J. Chu, "Removal of Ca(II) and $\mathrm{Mg}(\mathrm{II})$ from potassium chromate solution on Amberlite IRC 748 synthetic resin by ion exchange," Journal of Hazardous Materials, vol. 167, no. 1-3, pp. 406-412, 2009.

[25] C. Ghergheles, V. Ghergheles, T. Romocea et al., "Softening of waste geothermal water using ion exchange resins for environmental protection," Journal of Environmental Protection and Ecology, vol. 13, no. 3, pp. 1553-1559, 2012.

[26] C. Özmetin, Ö. Aydin, M. M. Kocakerim, M. Korkmaz, and E. Özmetin, "An empirical kinetic model for calcium removal from calcium impurity-containing saturated boric acid solution by ion exchange technology using Amberlite IR-120 resin," Chemical Engineering Journal, vol. 148, no. 2-3, pp. 420-424, 2009.

[27] C. Özmetin and Ö. Aydin, "A semi-empirical model for adsorption of magnesium ion from magnesium impurity-containing saturated boric acid solutions on amberlite IR-120 resin," Fresenius Environmental Bulletin, vol. 16, no. 7, pp. 720-725, 2007.

[28] Rohm and Haas Company, "Water Treatment Resin (Industrial Grade)," Product Data Sheet, IE-489 EDS, Corporate Headquarters 100 Independence Mall West Philadelphia, USA, 1998.

[29] Analytical Methods Varian Techtron Pty Limited Mulgrave Victoria Australia Publication no: 85-100009-00, 1989. 

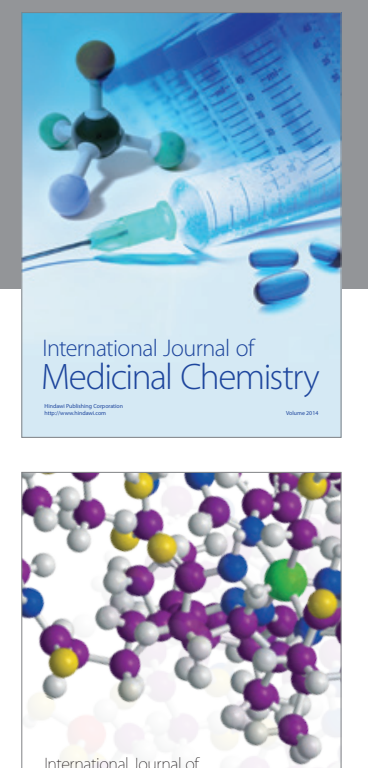

\section{Carbohydrate} Chemistry

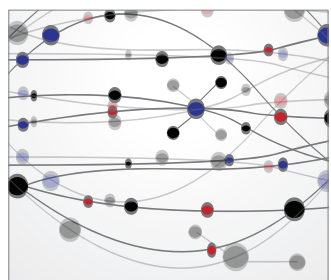

The Scientific World Journal
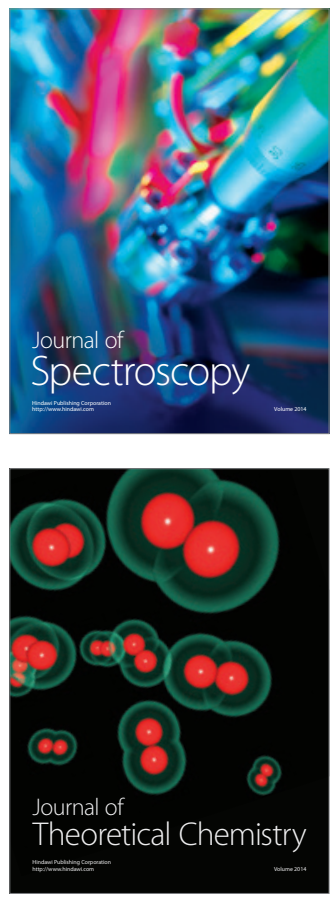
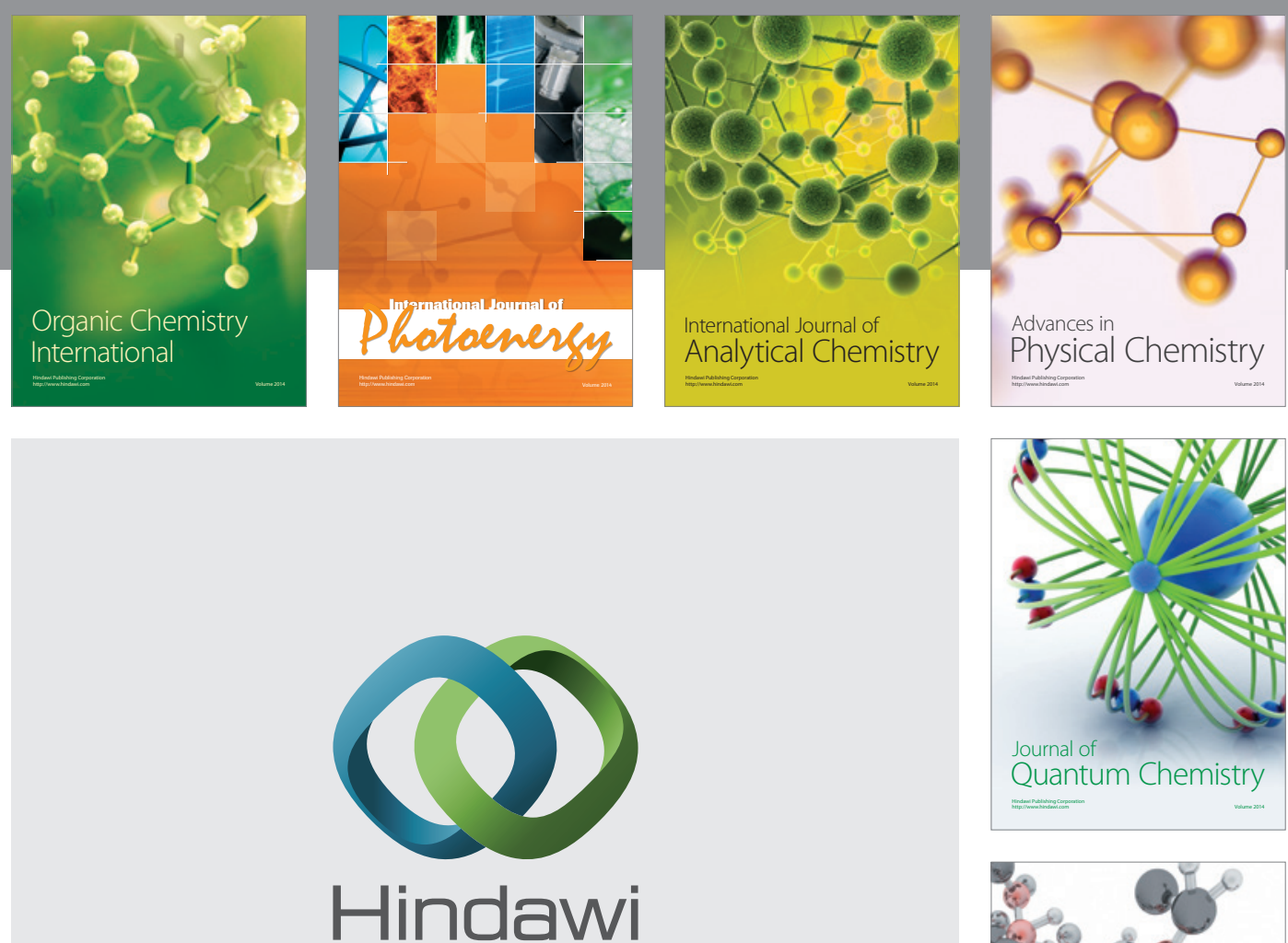

Submit your manuscripts at

http://www.hindawi.com

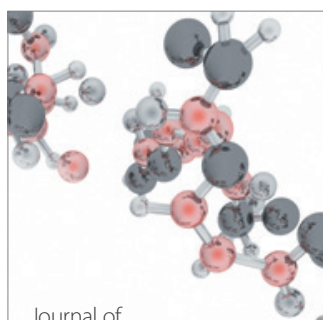

Analytical Methods

in Chemistry

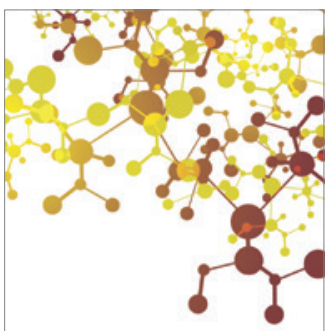

Journal of

Applied Chemistry

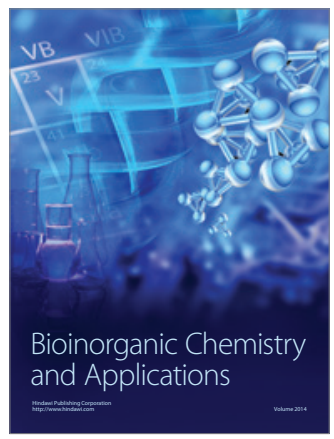

Inorganic Chemistry
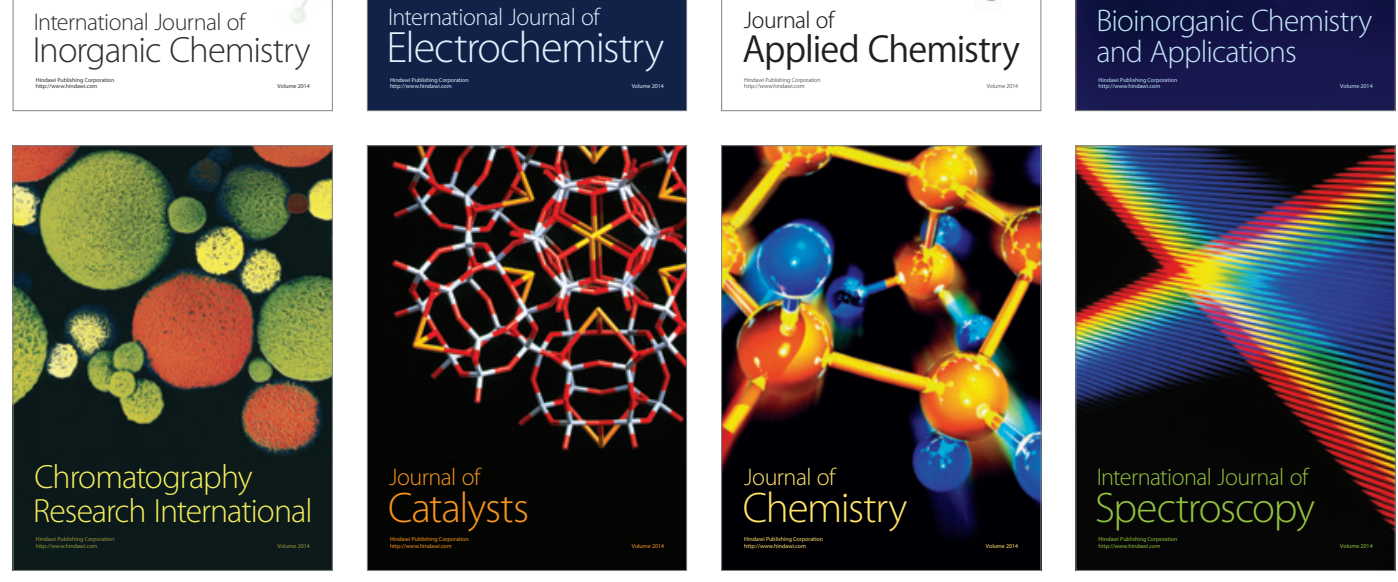